\title{
High tolerance of Chaetomorpha sp. to salinity and water temperature enables survival and growth in stagnant waters of central Thailand
}

\author{
Isao Tsutsui · Tatsuo Miyoshi $\cdot$ Dusit Aue-umneoy $\cdot$ Jaruwan Songphatkaew $•$ \\ Chonlada Meeanan • Sirimas Klomkling • Halethichanok Sukchai • \\ Piyarat Pinphoo - Iori Yamaguchi • Monthon Ganmanee • Yukio Maeno • \\ Kaoru Hamano
}

Received: 30 October 2014/Accepted: 12 December 2014/Published online: 14 January 2015

(C) The Author(s) 2015. This article is published with open access at Springerlink.com

\begin{abstract}
The effects of salinity and water temperature on growth and survival of Chaetomorpha sp., one of the green tidal filamentous algae, were investigated. Field surveys revealed that this alga was abundant throughout the year in stagnant coastal waters of central Thailand. Chaetomorpha sp. was found in salinities of 3.4-90.0 and water temperatures of 20.1-40.9 ${ }^{\circ} \mathrm{C}$. Chaetomorpha sp. biomass fluctuated between 9.2 and $162 \mathrm{~kg}$ dry weight in a saline swamp, without significant differences among seasons. The highest mean specific growth rate of approximately, $60 \%$ day $^{-1}$ was observed in laboratory experimental trials at salinities of $20-30$ at $30{ }^{\circ} \mathrm{C}$. Salinity and water temperature significantly affected growth of this alga independently and interactively. Based on these results, Chaetomorpha sp. can easily grow, survive and monopolize in stagnant waters where the salinity and temperature greatly fluctuate because of their euryhaline and eurythermal nature as well as their high growth rate.
\end{abstract}

Keywords Cladophoraceae $\cdot$ Euryhalinity $\cdot$ Eurythermy $\cdot$ Algal mat $\cdot$ Mangrove swamps

\section{Introduction}

Excessive blooms of ephemeral green seaweeds such as Ulva, Cladophora, and Chaetomorpha are referred to as green tide, which occurs in various regions worldwide. Although it is generally recognized that green tide is negative (Caffrey and Monahan 1999; Lehvo and Bäck 2001; Hiraoka et al. 2004; McAvoy and Klug 2005;

I. Tsutsui · Y. Maeno

Fisheries Division, Japan International Research Center for Agricultural Sciences (JIRCAS), Tsukuba, Ibaraki, Japan

T. Miyoshi $\cdot$ K. Hamano $(\square)$

National Research Institute of Fisheries and Environment of Inland Sea, Onomichi, Hiroshima, Japan

e-mail: hamano@affrc.go.jp

D. Aue-umneoy $\cdot$ J. Songphatkaew $\cdot$ P. Pinphoo $\cdot$ M. Ganmanee

Department of Animal Production and Fisheries, Faculty of Agricultural Technology, King Mongkut's Institute of

Technology Ladkrabang (KMITL), Bangkok, Thailand

C. Meeanan $\cdot$ S. Klomkling $\cdot$ H. Sukchai

Shrimp Co-culture Research Laboratory (SCORL), King Mongkut's Institute of Technology Ladkrabang (KMITL),

Bangkok, Thailand

I. Yamaguchi

Faculty of Engineering, Fukuoka Institute of Technology (FIT), Fukuoka, Japan 
Morand and Merceron 2005; Liu et al. 2009, 2013; Yamochi 2013), a part of green tide component seaweeds have positive aspects both ecologically and socially (Ohno 1993; Tsutsui et al. 2005, 2010, 2012; Bolton et al. 2009; de Paula Silva et al. 2008; Cruz-Suárez et al. 2010; Maceiras et al. 2011). For example, several species of Chaetomorpha were started to investigated for their applicability in integrated aquaculture with marine animals (de Paula Silva et al. 2008; Tsutsui et al. 2010).

Chaetomorpha is a cosmopolitan genus containing 81 species from marine and brackish waters worldwide (Leliaert and Boedeker 2007; Guiry and Guiry 2014). Eight species have been reported in Thailand, most of which occur along the coast (Lewmanomont et al. 1995; Lewmanomont and Ogawa 1995; Coppejans et al. 2010; Hamano et al. 2012; Tsutsui et al. 2012), whereas some occur in stagnant waters, including aquaculture ponds, aqueducts, and reservoirs, in the mangrove hinterlands (Tsutsui et al. 2012). Chaetomorpha are often included in the results of floral surveys because the genus is very common in coastal areas; however, very little ecophysiological information is available for this taxon (de Paula Silva et al. 2008; Xu and Lin 2008; Deng et al. 2012).

An unidentified Chaetomorpha sp. grows widely and abundantly all through the year in stagnant waters in the mangrove hinterlands of central Thailand. The objectives of the present study were to clarify the ecological conditions of Chaetomorpha sp. and evaluate its tolerance to salinity and water temperature. We demonstrate the reason for monopoly of this species in stagnant environments with a wide range of salinity (freshwater to brine water) and water temperature.

\section{Materials and methods}

All the research activities in this study including field surveys and laboratory experiments were permitted by National Research Council of Thailand (NRCT) (project ID 2011/005). A part of field survey sites was privately owned land, and the authors got oral approvals for sampling from all private land owners. The field studies did not involve endangered or protected species.

Study organism

An unidentified species Chaetomorpha sp. was used for this study. This alga is very thin, light to dark green in color, and soft to the touch; it consists of uniseriate unbranched filaments growing to 50-60 cm when fully developed. Lateral rhizoidal filaments are not observed at any time during the year. The cells are cylindrical, measuring $45-136 \mu \mathrm{m}$ in length and 27-64 $\mu \mathrm{m}$ in diameter (Fig. 1). The accession numbers of this seaweed at DDBJ were AB759541 and AB819998 for 18s rDNA and 28s rDNA, respectively.

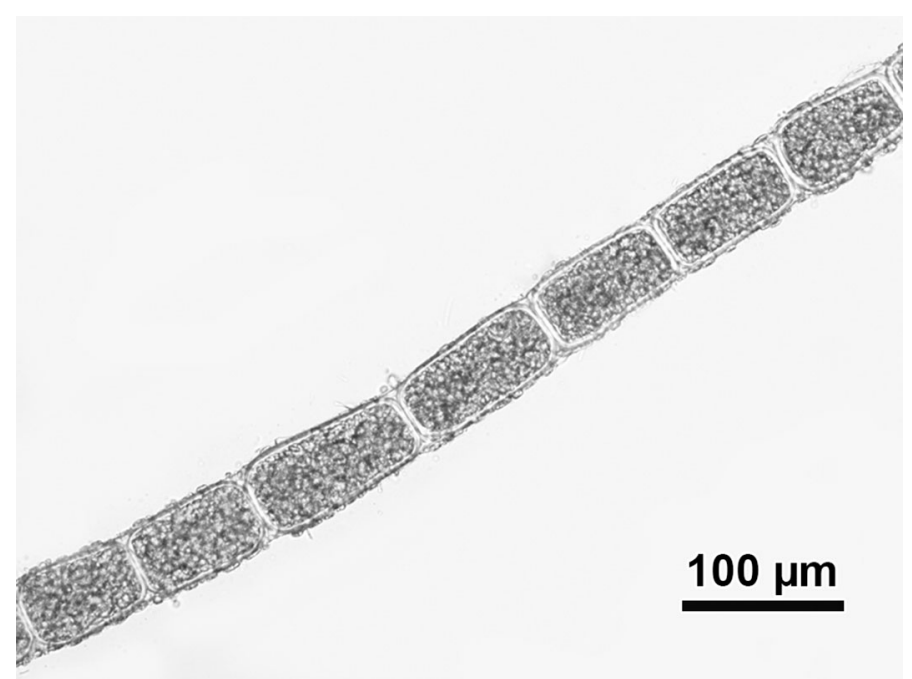

Fig. 1 A microscopic view of Chaetomorpha sp. A healthy and green colored vegetative filament is shown 
Field surveys

\section{Survey for habitat and habit}

A field survey to determine the habitat and habit of Chaetomorpha sp. was conducted in coastal areas of central Thailand from 2010 to 2013 (Fig. 2; Table 1). During the survey, salinity and water temperature were measured on site using a conductivity meter (Condo 3210, WTW Inc., Weilheim, Germany), and the types of habitats and habits were recorded. A small number of Chaetomorpha sp. thalli were directly collected by hand at each survey site and immediately placed in plastic bags with water, after which they were transported to the Shrimp Co-culture Research Laboratory (SCORL), Faculty of Agricultural Technology, King Mongkut's Institute of Technology Ladkrabang (KMITL), Thailand as samples for morphological observation. Sample morphology was observed under an optical microscope (BX 41, Olympus Co. Ltd., Tokyo, Japan) to identify the species. Some samples were dried and pressed and retained as herbarium specimens at SCORL.

\section{Survey for biomass fluctuations}

The biomass fluctuations of Chaetomorpha sp. were surveyed every 2 weeks from September 2011 to January 2013 in a small salt swamp, which is survey designation number 20 in Table 1 . This salt swamp was a semiclosed system with very little water exchange surrounded by a mangrove forest and aqueducts, and had a volume of approximately, $100 \mathrm{~m}^{3}$ at full capacity (Fig. 3c). A $16 \times 16-\mathrm{cm}$ quadrat was prepared with a mesh net to randomly cover a portion of the Chaetomorpha sp. community, and all thalli inside the quadrat were collected with scissors. Three replicates were collected during each survey. The total coverage of Chaetomorpha sp. was visually estimated, and the water surface area was measured using a laser distance meter (GLM 250 VF, Robert Bosch Inc., Stuttgart, Germany). In addition, salinity and water temperature was measured onsite using a conductivity meter (Condo 3210, WTW Inc.). Water samples were returned to SCORL, where they were analyzed for total inorganic nitrogen (TIN) and phosphate using a portable spectrophotometer (DR2400, Hach Co. Ltd., Loveland, CO, USA). Samples of Chaetomorpha sp. were immediately placed in plastic bags with water and transported to SCORL, where they were rinsed with fresh water to remove epiphytes and attached animals. The seaweed samples were then dried in a constant temperature oven (DK300, Yamato Scientific Co. Ltd., Tokyo, Japan) at $85{ }^{\circ} \mathrm{C}$ for $5 \mathrm{~h}$, after which the dry weights were measured on an electric balance (EK300H, A\&D Co. Ltd., Tokyo, Japan). Total biomass (TB) at the survey station was estimated using the following formula:

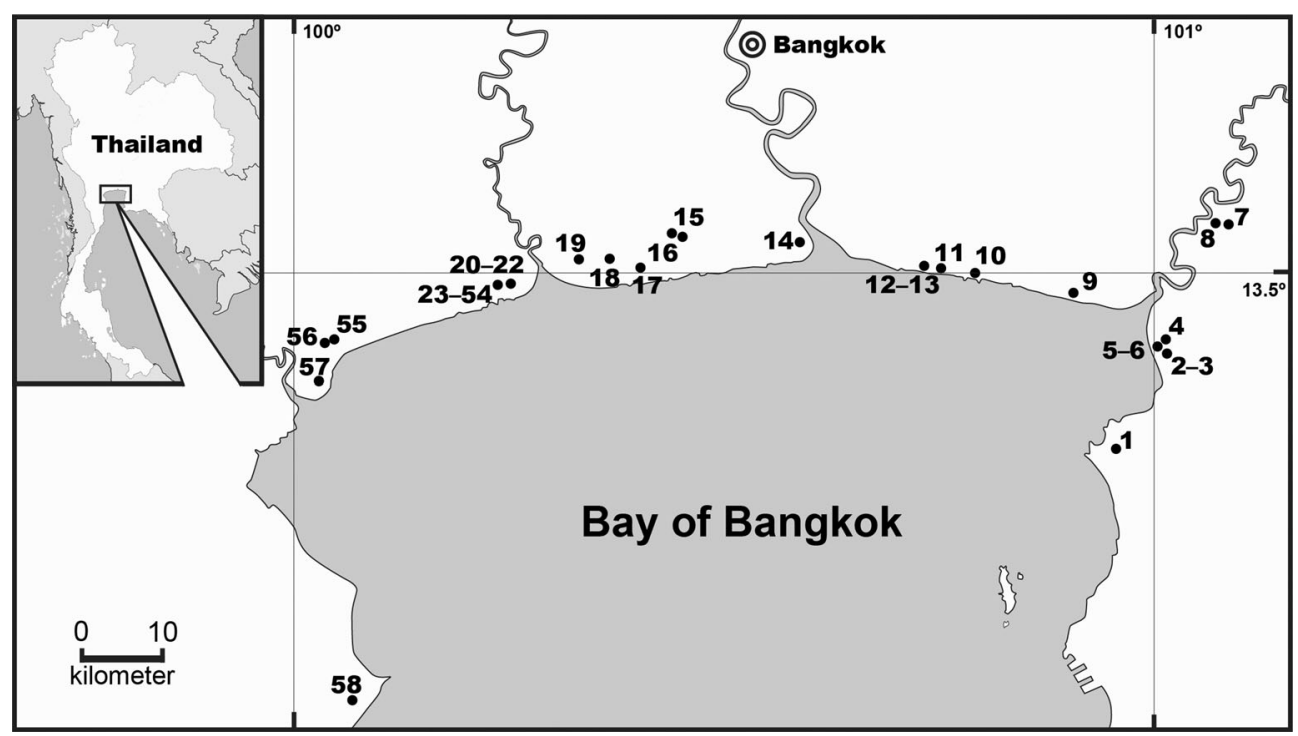

Fig. 2 Map showing locations for the habitat and habit field surveys in central Thailand. Numbers refer to the survey designation numbers in Table 1 
Table 1 Location, habitats, and habits of Chaetomorpha sp. surveyed in central Thailand

\begin{tabular}{|c|c|c|c|c|c|c|}
\hline No. & Location and date & Habitat & Area $\left(m^{2}\right)$ & Cover $(\%)$ & Depth (m) & Habit \\
\hline 01 & $\begin{array}{l}\text { AngSila, Chonburi } \\
\text { 06 July } 2011\end{array}$ & $\mathrm{RE}$ & 100 & 20 & 0.3 & $\mathrm{~F}, \mathrm{~B}$ \\
\hline 02 & $\begin{array}{l}\text { KhlongTamru, Chonburi } \\
\text { 06 July } 2011\end{array}$ & AA & 100 & 60 & 0.3 & $\mathrm{~F}, \mathrm{~B}$ \\
\hline 03 & $\begin{array}{l}\text { KhlongTamru, Chonburi } \\
\text { 06 July } 2011\end{array}$ & SW & 30 & 70 & 0.2 & $\mathrm{~F}, \mathrm{~B}$ \\
\hline 04 & $\begin{array}{l}\text { KhlongTamru, Chonburi } \\
\text { 06 July } 2011\end{array}$ & SW & 200 & 40 & 0.5 & $\mathrm{~F}, \mathrm{~B}$ \\
\hline 05 & $\begin{array}{l}\text { KhlongTamru, Chonburi } \\
\text { 09 July } 2013\end{array}$ & SW & 200 & 10 & 0.1 & $\mathrm{~F}, \mathrm{~B}$ \\
\hline 06 & $\begin{array}{l}\text { KhlongTamru, Chonburi } \\
\text { 06 July } 2011\end{array}$ & $\mathrm{RE}$ & 1,050 & 40 & 0.2 & $\mathrm{~F}, \mathrm{~B}$ \\
\hline 07 & $\begin{array}{l}\text { KhlongTamru, Chonburi } \\
\text { 09 July } 2013\end{array}$ & $\mathrm{RE}$ & 1,050 & 20 & 0.4 & $\mathrm{~F}, \mathrm{~B}$ \\
\hline 08 & $\begin{array}{l}\text { Bang Pu, Chachengsao } \\
\text { 05 July } 2013\end{array}$ & $\mathrm{RE}$ & 12,500 & 60 & 0.2 & $\mathrm{~F}, \mathrm{~B}$ \\
\hline 09 & $\begin{array}{l}\text { Bang Pakong, Chachengsao } \\
\text { 05 July } 2013\end{array}$ & $\mathrm{AP}$ & 1,450 & 20 & 0.2 & $\mathrm{~F}, \mathrm{~B}$ \\
\hline 10 & $\begin{array}{l}\text { Khlongdan, SamutPrakan } \\
19 \text { May } 2011\end{array}$ & AA & 100 & 40 & 0.5 & B \\
\hline 11 & $\begin{array}{l}\text { Bang Pu Mai, SamutPrakan } \\
19 \text { May } 2011\end{array}$ & SW & 50 & 40 & 0.4 & $\mathrm{~F}, \mathrm{~B}$ \\
\hline 12 & $\begin{array}{l}\text { Bang Pu Mai, SamutPrakan } \\
9 \text { July } 2013\end{array}$ & SW & 50 & 10 & 0.2 & $\mathrm{~F}, \mathrm{~B}$ \\
\hline 13 & $\begin{array}{l}\text { Muang, SamutPrakan } \\
\text { 05 July } 2013\end{array}$ & $\mathrm{RE}$ & 150 & 40 & 0.2 & F, B \\
\hline 14 & $\begin{array}{l}\text { LaemFaPha, SamutPrakan } \\
\text { 01 June } 2011\end{array}$ & AA & 100 & 70 & 0.2 & $\mathrm{~F}, \mathrm{~B}$ \\
\hline 15 & $\begin{array}{l}\text { Bang KhunThian, Bangkok } \\
22 \text { July } 2013\end{array}$ & RE & 46,100 & 5 & 0.5 & $\mathrm{~F}, \mathrm{~B}$ \\
\hline 16 & $\begin{array}{l}\text { Bang KhunThian, Bangkok } \\
22 \text { July } 2013\end{array}$ & AA & 200 & 60 & 0.5 & F, B \\
\hline 17 & $\begin{array}{l}\text { Muang, SamutSakhon } \\
22 \text { July } 2013\end{array}$ & $\mathrm{AP}$ & 550 & 50 & 0.4 & $\mathrm{~F}, \mathrm{~B}$ \\
\hline 18 & $\begin{array}{l}\text { Muang, SamutSakhon } \\
22 \text { July } 2013\end{array}$ & $\mathrm{AP}$ & 640 & 40 & 0.1 & $\mathrm{~F}, \mathrm{~B}$ \\
\hline 19 & $\begin{array}{l}\text { Muang, SamutSakhon } \\
22 \text { July } 2013\end{array}$ & AA & 110 & 60 & 0.5 & $\mathrm{~F}, \mathrm{~B}$ \\
\hline 20 & $\begin{array}{l}\text { Chai Mongkhon, SamutSakhon } \\
03 \text { August } 2011\end{array}$ & SW & 100 & 75 & 0.6 & $\mathrm{~F}, \mathrm{~B}$ \\
\hline 21 & $\begin{array}{l}\text { Chai Mongkhon, SamutSakhon } \\
23 \text { December } 2013\end{array}$ & SW & 100 & 75 & 0.6 & $\mathrm{~F}, \mathrm{~B}$ \\
\hline 22 & $\begin{array}{l}\text { Chai Mongkhon, SamutSakhon } \\
29 \text { December } 2013\end{array}$ & SW & 100 & 75 & 0.6 & $\mathrm{~F}, \mathrm{~B}$ \\
\hline 23 & $\begin{array}{l}\text { Chai Mongkhon, SamutSakhon } \\
25 \text { November } 2011\end{array}$ & AP & 230 & 80 & 0.6 & $\mathrm{~F}, \mathrm{~B}$ \\
\hline 24 & $\begin{array}{l}\text { Chai Mongkhon, SamutSakhon } \\
14 \text { December } 2011\end{array}$ & $\mathrm{AP}$ & 190 & 80 & 0.6 & $\mathrm{~F}, \mathrm{~B}$ \\
\hline
\end{tabular}


Table 1 continued

\begin{tabular}{|c|c|c|c|c|c|c|}
\hline No. & Location and date & Habitat & Area $\left(\mathrm{m}^{2}\right)$ & Cover $(\%)$ & Depth (m) & Habit \\
\hline 25 & $\begin{array}{l}\text { Chai Mongkhon, SamutSakhon } \\
28 \text { December } 2011\end{array}$ & AP & 75 & 70 & 0.6 & $\mathrm{~F}, \mathrm{~B}$ \\
\hline 26 & $\begin{array}{l}\text { Chai Mongkhon, SamutSakhon } \\
18 \text { January } 2012\end{array}$ & AP & 230 & 10 & 0.7 & $\mathrm{~F}, \mathrm{~B}$ \\
\hline 27 & $\begin{array}{l}\text { Chai Mongkhon, SamutSakhon } \\
01 \text { February } 2012\end{array}$ & AP & 230 & 10 & 0.7 & $\mathrm{~F}, \mathrm{~B}$ \\
\hline 28 & $\begin{array}{l}\text { Chai Mongkhon, SamutSakhon } \\
15 \text { February } 2012\end{array}$ & AP & 180 & 5 & 0.6 & $\mathrm{~F}, \mathrm{~B}$ \\
\hline 29 & $\begin{array}{l}\text { Chai Mongkhon, SamutSakhon } \\
29 \text { February } 2012\end{array}$ & AP & 150 & 5 & 0.5 & $\mathrm{~F}, \mathrm{~B}$ \\
\hline 30 & $\begin{array}{l}\text { Chai Mongkhon, SamutSakhon } \\
14 \text { March } 2012\end{array}$ & AP & 230 & 70 & 0.7 & $\mathrm{~F}$ \\
\hline 31 & $\begin{array}{l}\text { Chai Mongkhon, SamutSakhon } \\
28 \text { March } 2012\end{array}$ & AP & 230 & 20 & 0.7 & $\mathrm{~F}$ \\
\hline 32 & $\begin{array}{l}\text { Chai Mongkhon, SamutSakhon } \\
12 \text { April } 2012\end{array}$ & AP & 230 & 15 & 0.7 & $\mathrm{~F}, \mathrm{~B}$ \\
\hline 33 & $\begin{array}{l}\text { Chai Mongkhon, SamutSakhon } \\
28 \text { April } 2012\end{array}$ & AP & 180 & 20 & 0.7 & $\mathrm{~F}, \mathrm{~B}$ \\
\hline 34 & $\begin{array}{l}\text { Chai Mongkhon, SamutSakhon } \\
09 \text { May } 2012\end{array}$ & $\mathrm{AP}$ & 75 & 30 & 0.4 & $\mathrm{~F}, \mathrm{~B}$ \\
\hline 35 & $\begin{array}{l}\text { Chai Mongkhon, SamutSakhon } \\
23 \text { May } 2012\end{array}$ & $\mathrm{AP}$ & 230 & 20 & 0.7 & $\mathrm{~F}, \mathrm{~B}$ \\
\hline 36 & $\begin{array}{l}\text { Chai Mongkhon, SamutSakhon } \\
\text { 06 June } 2012\end{array}$ & AP & 230 & 20 & 0.7 & $\mathrm{~F}, \mathrm{~B}$ \\
\hline 37 & $\begin{array}{l}\text { Chai Mongkhon, SamutSakhon } \\
20 \text { June } 2012\end{array}$ & AP & 230 & 70 & 0.7 & $\mathrm{~F}, \mathrm{~B}$ \\
\hline 38 & $\begin{array}{l}\text { Chai Mongkhon, SamutSakhon } \\
\text { 04 July } 2012\end{array}$ & AP & 230 & 80 & 0.7 & $\mathrm{~F}, \mathrm{~B}$ \\
\hline 39 & $\begin{array}{l}\text { Chai Mongkhon, SamutSakhon } \\
18 \text { July } 2012\end{array}$ & AP & 230 & 80 & 0.7 & $\mathrm{~F}, \mathrm{~B}$ \\
\hline 40 & $\begin{array}{l}\text { Chai Mongkhon, SamutSakhon } \\
01 \text { August } 2012\end{array}$ & AP & 200 & 80 & 0.6 & $\mathrm{~F}, \mathrm{~B}$ \\
\hline 41 & $\begin{array}{l}\text { Chai Mongkhon, SamutSakhon } \\
17 \text { August } 2012\end{array}$ & $\mathrm{AP}$ & 200 & 70 & 0.6 & $\mathrm{~F}, \mathrm{~B}$ \\
\hline 42 & $\begin{array}{l}\text { Chai Mongkhon, SamutSakhon } \\
31 \text { August } 2012\end{array}$ & AP & 200 & 40 & 0.6 & $\mathrm{~F}, \mathrm{~B}$ \\
\hline 43 & $\begin{array}{l}\text { Chai Mongkhon, SamutSakhon } \\
14 \text { September } 2012\end{array}$ & AP & 230 & 60 & 0.7 & $\mathrm{~F}, \mathrm{~B}$ \\
\hline 44 & $\begin{array}{l}\text { Chai Mongkhon, SamutSakhon } \\
27 \text { September } 2012\end{array}$ & AP & 230 & 60 & 0.7 & $\mathrm{~F}, \mathrm{~B}$ \\
\hline 45 & $\begin{array}{l}\text { Chai Mongkhon, SamutSakhon } \\
26 \text { Ocober } 2012\end{array}$ & AP & 230 & 60 & 0.7 & $\mathrm{~F}, \mathrm{~B}$ \\
\hline 46 & $\begin{array}{l}\text { Chai Mongkhon, SamutSakhon } \\
27 \text { September } 2012\end{array}$ & AP & 200 & 30 & 0.6 & $\mathrm{~F}, \mathrm{~B}$ \\
\hline 47 & $\begin{array}{l}\text { Chai Mongkhon, SamutSakhon } \\
7 \text { November } 2012\end{array}$ & AP & 230 & 10 & 0.7 & $\mathrm{~F}, \mathrm{~B}$ \\
\hline 48 & $\begin{array}{l}\text { Chai Mongkhon, SamutSakhon } \\
5 \text { December } 2012\end{array}$ & AP & 230 & 5 & 0.7 & $\mathrm{~F}, \mathrm{~B}$ \\
\hline
\end{tabular}


Table 1 continued

\begin{tabular}{|c|c|c|c|c|c|c|}
\hline No. & Location and date & Habitat & Area $\left(\mathrm{m}^{2}\right)$ & Cover $(\%)$ & Depth (m) & Habit \\
\hline 49 & $\begin{array}{l}\text { Chai Mongkhon, SamutSakhon } \\
19 \text { December } 2012\end{array}$ & $\mathrm{AP}$ & 150 & 5 & 0.5 & $\mathrm{~F}, \mathrm{~B}$ \\
\hline 50 & $\begin{array}{l}\text { Chai Mongkhon, SamutSakhon } \\
2 \text { February } 2013\end{array}$ & $\mathrm{AP}$ & 150 & 50 & 0.5 & $\mathrm{~F}, \mathrm{~B}$ \\
\hline 51 & $\begin{array}{l}\text { Chai Mongkhon, SamutSakhon } \\
16 \text { February } 2013\end{array}$ & $\mathrm{AP}$ & 160 & 20 & 0.6 & $\mathrm{~F}, \mathrm{~B}$ \\
\hline 52 & $\begin{array}{l}\text { Chai Mongkhon, SamutSakhon } \\
2 \text { March } 2013\end{array}$ & AP & 180 & 50 & 0.7 & $\mathrm{~F}, \mathrm{~B}$ \\
\hline 53 & $\begin{array}{l}\text { Chai Mongkhon, SamutSakhon } \\
15 \text { April } 2013\end{array}$ & AP & 230 & 5 & 0.7 & $\mathrm{~F}, \mathrm{~B}$ \\
\hline 54 & $\begin{array}{l}\text { Chai Mongkhon, SamutSakhon } \\
11 \text { June } 2013\end{array}$ & $\mathrm{AP}$ & 230 & 5 & 0.7 & $\mathrm{~F}$ \\
\hline 55 & $\begin{array}{l}\text { LatYai, SamutSongkhram } \\
29 \text { June } 2010\end{array}$ & AA & 600 & 40 & 0.7 & $\mathrm{~F}, \mathrm{~B}$ \\
\hline 56 & $\begin{array}{l}\text { LatYai, SamutSongkhram } \\
22 \text { September } 2010\end{array}$ & AQ & 800 & 70 & 1.0 & $\mathrm{~F}, \mathrm{~B}$ \\
\hline 57 & $\begin{array}{l}\text { LatYai, SamutSongkhram } \\
22 \text { September } 2010\end{array}$ & AQ & 800 & 40 & 1.0 & B \\
\hline 58 & $\begin{array}{l}\text { LaemPhakBia, Phetchaburi } \\
19 \text { September } 2012\end{array}$ & $\mathrm{AP}$ & 60 & 50 & 0.3 & $\mathrm{~F}, \mathrm{~B}$ \\
\hline
\end{tabular}

$A A$ aqueduct for aquaculture/salt field, $A P$ abandoned aqueduct/pond, $A Q$ aquaculture pond, $R E$ reservoir, $S W$ salt swamp, $F$ floating strand from bottom, $B$ dense mat on bottom
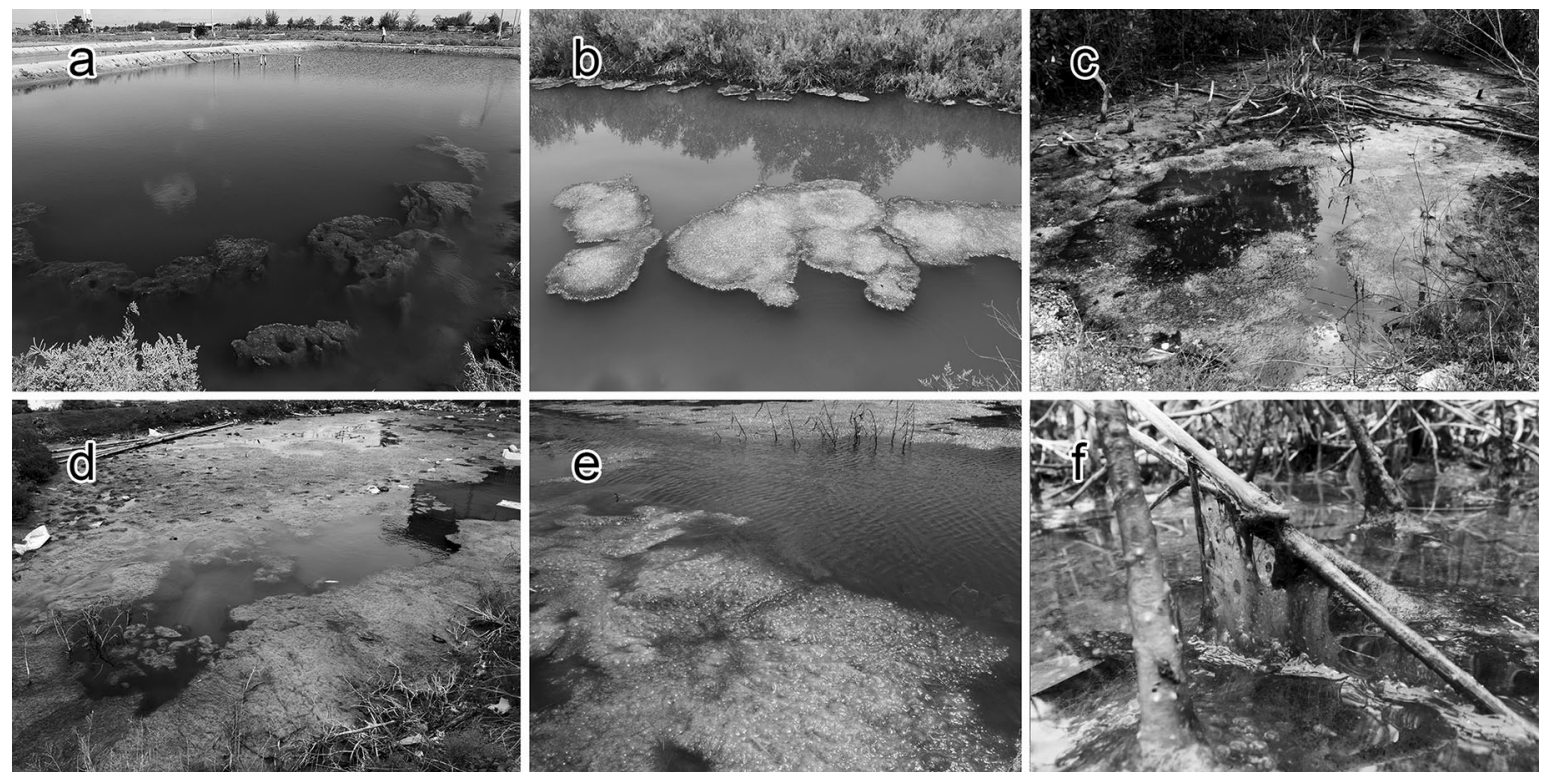

Fig. 3 Chaetomorpha sp. in natural habitats. a Plants forming dense and submerged tangled mats on the bottom of an aquaculture pond; b plants forming floating strands that cover the water surface in a shrimp culture aqueduct; $\mathbf{c}$ plants covering the water surface in a salt swamp; $\mathbf{d}$ plants growing in an abandoned aquaculture pond; $\mathbf{e}$ plants propagating in a reservoir; $\mathbf{f}$ close-up view of plants growing in a salt swamp 
TB $(\mathrm{kg} \mathrm{DW})=\mathrm{DW}$ of samples $/(0.16 \times 0.16) \times$ total area $\left(\mathrm{m}^{2}\right)$

where DW is dry weight.

Preparation for laboratory experiments

Plants collected at survey designation number 20 in Table 1 and cultured at SCORL were utilized for survival and growth experiments. Prior to the experiments, powdered, artificial seawater (Rhoto Marine II, Rei-Sea Co. Ltd., Tokyo, Japan) was diluted with distilled water and adjusted to salinities of 0.1, 0.2, 0.5, 5, 10, 20, 30, 40, 50, 60, 70, and 80 using a conductivity meter (Condo 3210, WTW Inc.), and distilled water was used for the 0 salinity treatment. These experimental media were sterilized at $121^{\circ} \mathrm{C}$ for $20 \mathrm{~min}$ using an autoclave (HVE50, Hirayama Manufacturing Corp., Saitama, Japan), after which the $\mathrm{pH}$ was adjusted to 8.0 with $\mathrm{NaOH}$ using a pH meter (SevenGo, Mettler Toledo, Schwerzenbach, Switzerland). As a nutrient source, a ratio of $3 \mathrm{~mL}$ of stock solution of Provasoli's enriched seawater (PES) in $1 \mathrm{~L}$ artificial seawater or freshwater (approximately, 1/6 concentration of PES) was used (Provasoli 1966), and germanium dioxide $\left(3 \mathrm{mg} \mathrm{L}^{-1}\right)$ was added to prevent growth of diatoms (Lewin 1966). Plants cultured at SCORL were cut into small pieces and then acclimated to each of the experimental salinities for 1 week. Chaetomorpha sp. was then cut into smaller pieces approximately, $2 \mathrm{~mm}$ in length using surgical scissors to prevent maturation (Tanaka 2001). Individual healthy filaments (without epiphytes or damage) measuring exactly $2.0 \mathrm{~mm}$ in length were selected using a stereomicroscope (SZX12, Olympus Co. Ltd., Tokyo, Japan) for the experiment.

Laboratory experiments

\section{Experiment for survival}

The 2.0-mm filaments were individually placed in each well with $1.8 \mathrm{~mL}$ of media of various salinities in multiwell plates. Twenty individuals were used for the experiment involving each combination of salinity $(0$, $0.1,0.2,0.5,5,10,20,30,40,50,60,70$, and 80$)$ and water temperature $\left(15,20,25,30,35\right.$, and $\left.40{ }^{\circ} \mathrm{C}\right)$. The multiplates were placed in a temperature gradient chamber (TG-180CCFL-3LE, Nippon Medical and Chemical Instruments Co. Ltd., Osaka, Japan) under a 12:12 h light:dark cycle and photon flux density of approximately, $70 \mu \mathrm{mol} \mathrm{m} \mathrm{m}^{-2} \mathrm{~s}^{-1}$. The algae were cultured for 7 days. This culture duration was determined with our preliminary work and previous works (Matsuyama-Serisawa et al. 2004; de Paula Silva et al. 2008). At the end of the experimental period, algae in each of the treatments were observed under a stereomicroscope. The surviving and dead filaments were identified, and survival rates were calculated. We defined green filaments as live filaments (Fig. 1), and clear and empty ones without any pores, from which zoospores or gametes could be released, as dead filaments.

\section{Experiment for growth rate}

Twenty filaments, $2.0 \mathrm{~mm}$ in length, were individually cultured in each well of the multiwell plates with $1.8 \mathrm{~mL}$ of media of various salinities as described for the survival experiment above. The salinities were 0 , $0.1,0.2,0.5,5,10,20,30,40,50,60,70$, and 80 and the water temperatures were $15,20,25,30$, and $35{ }^{\circ} \mathrm{C}$ for the growth experiment. Multiwell plates were set in the same incubation conditions, e.g., light cycle and photon flux density and the algae were cultured for 7 days. At the end of this period, individual algal lengths were measured under a stereomicroscope in each combination of salinity and water temperature. Specific growth rates (SGR) were calculated using the following formula:

$$
\operatorname{SGR}\left(\% \text { day }^{-1}\right)=\left(\ln L_{\mathrm{t}}-\ln L_{\mathrm{i}}\right) \times D^{-1} \times 100
$$

where $L_{\mathrm{t}}$ is final total length, $L_{\mathrm{i}}$ is initial length, and $D$ is culture duration. 
Experiment for growth patterns

After the survival and SGR experiments, the growth patterns of Chaetomorpha sp. were examined under optimum salinities for each water temperature, e.g., salinities of 10, 10, 20, 30, and 30 in water temperatures of $15,20,25,30$, and $35^{\circ} \mathrm{C}$, respectively. Filaments of $2.0 \mathrm{~mm}$ were cultured in multiwell plates under the same incubation conditions. Algal lengths of each Chaetomorpha sp. filament were measured under a stereomicroscope every day for 7 days.

\section{Statistical analysis}

Mean values are stated \pm their standard error (SE). Statistical analyses were performed using the software JMP10 (SAS Institute, Cary, NC, USA). Differences in mean biomass and mean physical and chemical environmental factors among seasons during the field survey were analyzed by the Tukey-Kramer HSD test $(P<0.05)$. Receiver operating characteristic $(\mathrm{ROC})$ analysis was adopted to determine the cut-off values for survival of the seaweed related to salinity and water temperature. The area under the curve (AUC) of the ROC curve was used to determine adequacy. The best cut-off point was selected as the highest value of sensitivity - $(1-$ specificity). Logistic regression analysis was then used to consider the relationship among survival of this seaweed in combinations of salinities and water temperatures, which were determined from the result of ROC analysis. A two-way random-effects analysis of variance (ANOVA) was followed by the Tukey-Kramer HSD test (ad hoc test) to compare the effect of salinity and water temperature on growth of Chaetomorpha sp.

\section{Results}

Habitat and habit

Chaetomorpha sp. was abundant in shallow and stagnant waters with little water exchange, including aquaculture ponds, salt swamps, aqueducts supplying salt fields, and abandoned aquaculture ponds at mangrove hinterlands in coastal areas (Table 1). The stagnant water area ranged from 30 to $46,100 \mathrm{~m}^{2}$ but usually covered $100-500 \mathrm{~m}^{2}$. Plants formed entwined spongy mats lying loosely on the bottom and frequently grew upwards as long interwoven strands covering the water surface (Fig. 3). This alga was found in water with salinity and water temperature ranges of 3.4-90.0 and 20.1-40.9 ${ }^{\circ} \mathrm{C}$, respectively (Fig. 4a). Approximately, $35 \%$ of these sites were within the salinity range of $20-30$, and $50 \%$ were between 30 and $35{ }^{\circ} \mathrm{C}$ (Fig. $4 \mathrm{~b}, \mathrm{c}$ ). No obvious relationship was detected in the distribution between salinity and water temperature.

Seasonal change in biomass

Changes in estimated total biomass and physical and chemical factors at the survey station are shown in Fig. 5 . Total biomass fluctuated, rising and falling slightly throughout the year between 9.2 and $162.0 \mathrm{~kg} \mathrm{DW}$, and peaks were observed at 2-4-month intervals. Mean total biomass was presented as standard error (SE) and the values were $94.6 \pm 8.39,86.0 \pm 20.47$, and $58.1 \pm 17.50 \mathrm{~kg} \mathrm{DW}$ during the rainy season (June-November), dry-cold season (December-February), and dry-hot season (March-May), respectively, without significant differences among seasons (Table 2). Salinity fluctuated between 6.0 and 44.0, and tended to stably increase from the late rainy season to the middle dry season with a small rise and fall. Mean salinity $( \pm \mathrm{SE})$ was lowest at $20.8 \pm 2.68$ during the rainy season, and this value significantly differed from the salinity of $30.4 \pm 2.41$ observed during the dry-cold season and $32.2 \pm 2.97$ observed during the dry-hot season. In addition, water temperature varied between 23.5 and $36.6^{\circ} \mathrm{C}$. The lowest mean $( \pm \mathrm{SE})$ water temperature was $29.8{ }^{\circ} \mathrm{C} \pm 1.10^{\circ} \mathrm{C}$ during the dry-cold season and the highest was $32.6{ }^{\circ} \mathrm{C} \pm 0.96{ }^{\circ} \mathrm{C}$ during the dry-hot season. Significant differences were observed between the rainy and dry-hot seasons and dry-cold and dry-hot seasons. Nutrient conditions were highly eutrophicated in the salt swamp of the survey station, as indicated by the TIN values of $1.0-3.6 \mathrm{mg} \mathrm{L}^{-1}$ and phosphate values of $2.0-7.6 \mathrm{mg} \mathrm{L}^{-1}$. No significant differences in TIN or phosphate were observed among seasons. U. intestinalis and U. clathrata opportunistically appeared several times at this survey station; however, their coverage was $<5 \%$. 

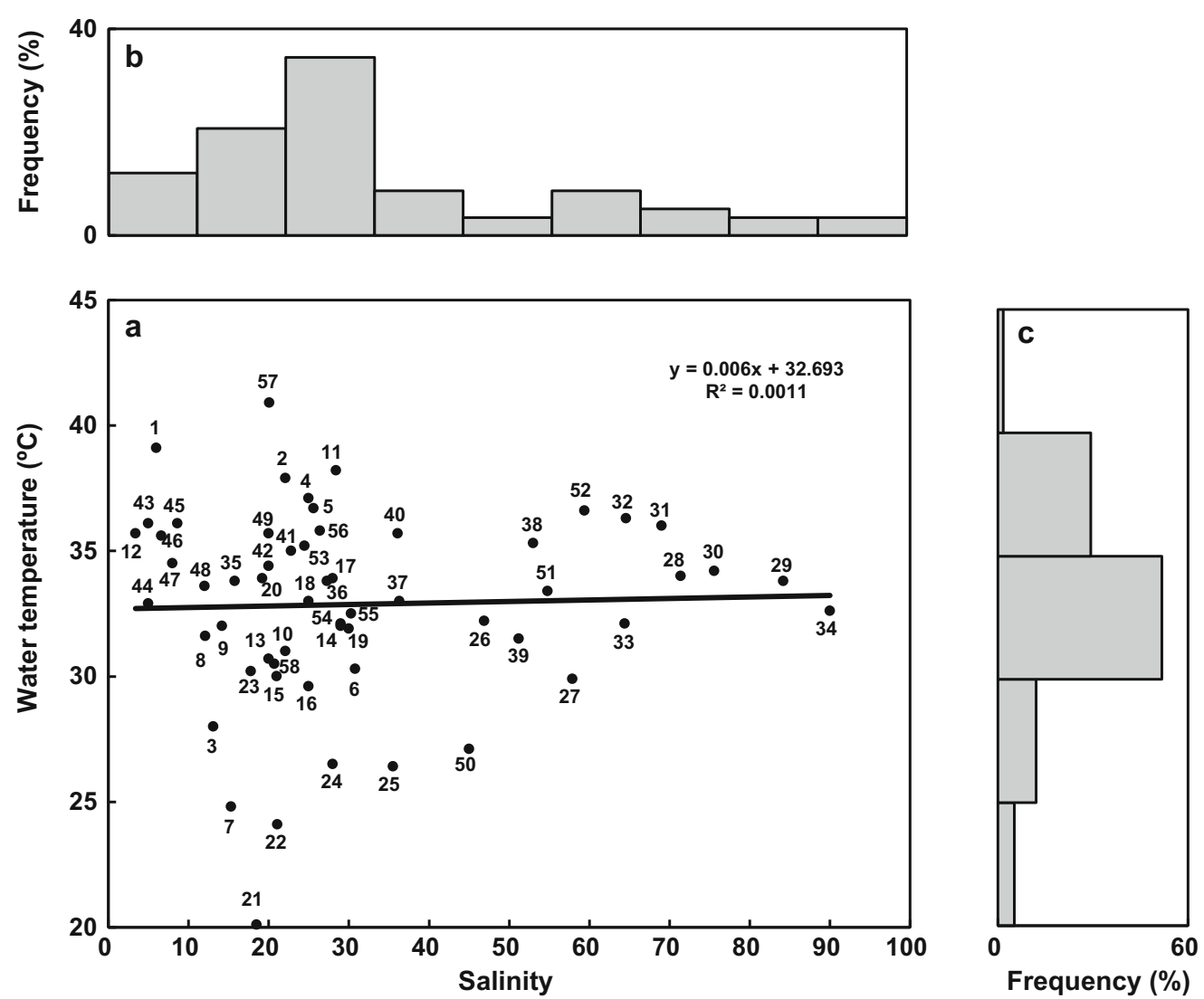

Fig. 4 Salinities and water temperatures in the natural habitats of Chaetomorpha sp. in central Thailand. a Scatter plot showing combinations at every station. Numbers in the plot area refer to the survey designation nos. in Table 1 ; $\mathbf{b}$ frequency distributions of salinity; c frequency distributions of water temperature

Survival at different salinities and water temperatures

Chaetomorpha sp. exhibited $100 \%$ survival over the salinity range of $0.5-80$ and water temperatures of $15-35^{\circ} \mathrm{C}$ (Table 3). Even at a salinity of 0 , survival rate was 35-70\% at temperatures of $20-30{ }^{\circ} \mathrm{C}$. However, survival was very low in all experimental salinities at $40{ }^{\circ} \mathrm{C}$. Results of the ROC analysis showed that the best cut-off values were observed between 0 and 0.1 for salinity (AUC 0.6718) and between $35{ }^{\circ} \mathrm{C}$ and $40{ }^{\circ} \mathrm{C}$ for water temperature (AUC 0.8819). These tendencies were statistically analyzed using a logistic regression model. Significant differences were observed between the combination of salinity of 0.1-80 and water temperature of $15-35{ }^{\circ} \mathrm{C}$ and at other combinations of salinity and water temperatures (Table 4).

SGR under different salinities and water temperatures

The highest mean ( \pm SE) growth rates of Chaetomorpha sp. in 7 days were observed at salinities of 20 and 30 at a water temperature of $30{ }^{\circ} \mathrm{C}\left(59.8 \pm 4.34\right.$ and $61.0 \pm 3.24 \%$ day ${ }^{-1}$, respectively; Figs. 6, 7). The highest individual SGR was $68.2 \%$ in a filament that grew from 2 to $237 \mathrm{~mm}$ at a salinity of 30 and water temperature of $30{ }^{\circ} \mathrm{C}$. As water temperature increased, SGR peaks shifted to higher salinities (Fig. 6), with the peak SGR occurring at a salinity of 10 at 15 and $20{ }^{\circ} \mathrm{C}$, at a salinity of 20 at $25{ }^{\circ} \mathrm{C}$, and at a salinity of 30 at 30 and $35{ }^{\circ} \mathrm{C}$. The results of a two-way random-effects ANOVA showed that both salinity and water temperature significantly affected growth of Chaetomorpha sp. independently and interactively (Table 5). As the result of Tukey-Kramer HSD test (ad hoc test), significant differences were observed in all pairwise comparisons of water temperature. In addition, significant differences were observed in almost all pairwise comparisons of salinities, except for the combination of salinity 0 vs. $0.1,0$ vs. $80,0.1$ vs. 80 , and 0.2 vs. 80 . 
Fig. 5 Fluctuations in total biomass of Chaetomorpha sp., and several physical factors at survey station. Data are mean \pm standard error: $R$, rainy season; $\mathrm{DC}$, cold period during dry season; DH, hot period during dry season
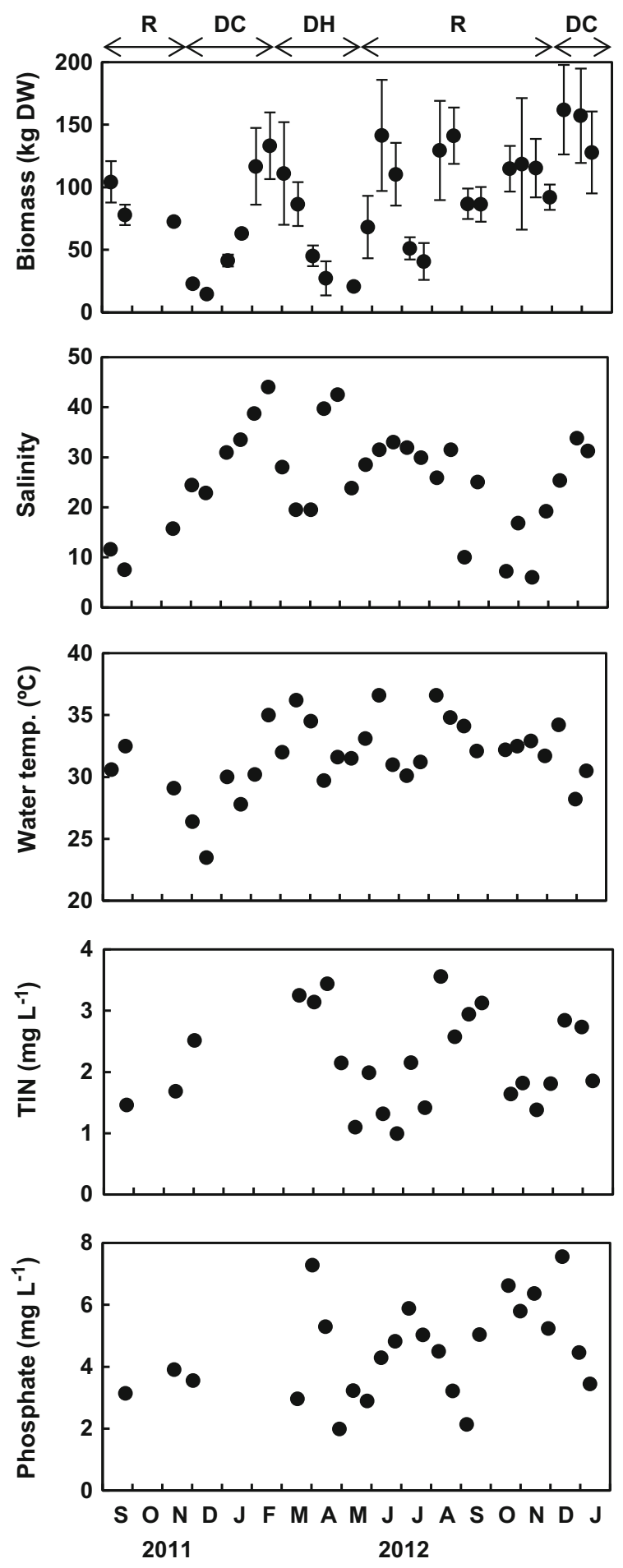

Growth patterns

The increase in lengths of Chaetomorpha sp. at optimum salinity under different water temperatures during the final 7 days of the experiment was reflected as quadratic curves (Fig. 8). A maximum mean length ( \pm SE) of $151.9 \pm 4.06 \mathrm{~mm}$ was observed on the last day in a salinity of 30 at $30{ }^{\circ} \mathrm{C}$, followed by a salinity of 30 at $35{ }^{\circ} \mathrm{C}$, a salinity of 20 at $25^{\circ} \mathrm{C}$, a salinity of 10 at $20^{\circ} \mathrm{C}$, and a salinity of 10 at $15{ }^{\circ} \mathrm{C}$. This growth tendency was the same as that observed in the SGR experiment; however, terminal mean lengths at each water temperature were shorter compared with those of the SGR experiment. 
Table 2 Mean biomass of Chaetomorpha sp., several physical factors at the survey station during different seasons

\begin{tabular}{|c|c|c|c|}
\hline & \multirow[t]{2}{*}{ Rainy season } & \multicolumn{2}{|l|}{ Dry season } \\
\hline & & Cold period & Hot period \\
\hline \multicolumn{4}{|c|}{ Total biomass (kg DW) } \\
\hline Mean total biomass & $94.6 \pm 8.39^{\mathrm{a}}$ & $86.0 \pm 20.47^{\mathrm{a}}$ & $58.1 \pm 17.50^{\mathrm{a}}$ \\
\hline Maximum & 141.3 & 162.0 & 110.0 \\
\hline Minimum & 40.8 & 9.2 & 20.7 \\
\hline \multicolumn{4}{|l|}{ Salinity } \\
\hline Mean & $20.8 \pm 2.68^{\mathrm{a}}$ & $30.4 \pm 2.41^{\mathrm{b}}$ & $32.2 \pm 2.97^{\mathrm{b}}$ \\
\hline Maximum & 33.0 & 44.0 & 42.5 \\
\hline Minimum & 6.0 & 19.2 & 23.8 \\
\hline \multicolumn{4}{|c|}{ Water temperature $\left({ }^{\circ} \mathrm{C}\right)$} \\
\hline Mean & $32.6 \pm 0.56^{\mathrm{a}}$ & $29.8 \pm 1.10^{\mathrm{b}}$ & $32.6 \pm 0.96^{\mathrm{a}, \mathrm{b}}$ \\
\hline Maximum & 36.6 & 35.0 & 36.2 \\
\hline Minimum & 29.1 & 23.5 & 29.7 \\
\hline \multicolumn{4}{|c|}{ Total nitrogen $\left(\mathrm{mg} \mathrm{L}^{-1}\right)$} \\
\hline Mean & $2.0 \pm 0.21^{\mathrm{a}}$ & $2.3 \pm 0.21^{\mathrm{a}}$ & $2.6 \pm 0.43^{\mathrm{a}}$ \\
\hline Maximum & 3.6 & 2.8 & 3.4 \\
\hline Minimum & 1.0 & 1.8 & 1.1 \\
\hline \multicolumn{4}{|c|}{ Dissolved phosphate $\left(\mathrm{mg} \mathrm{L}^{-1}\right)$} \\
\hline Mean & $4.5 \pm 0.37^{\mathrm{a}}$ & $4.8 \pm 0.75^{\mathrm{a}}$ & $4.1 \pm 0.95^{\mathrm{a}}$ \\
\hline Maximum & 6.6 & 7.6 & 7.3 \\
\hline Minimum & 2.1 & 3.4 & 2.0 \\
\hline
\end{tabular}

Data were collected during 2011 to 2013 in SamutSakhon Province, Thailand. Values are mean \pm standard error. Superscripts in the same column indicate homogeneous subsets as determined by the Tukey-Kramer HSD test $(P<0.05)$

Table 3 Survival rates of Chaetomorpha sp. cultured under various salinities and water temperatures for 7 days

\begin{tabular}{|c|c|c|c|c|c|c|}
\hline \multirow[t]{2}{*}{ Salinity } & \multicolumn{6}{|c|}{ Water temperature $\left({ }^{\circ} \mathrm{C}\right)$} \\
\hline & 15 & 20 & 25 & 30 & 35 & 40 \\
\hline 0 & 0 & 35 & 70 & 40 & 0 & 0 \\
\hline 0.1 & 100 & 100 & 100 & 15 & 40 & 0 \\
\hline 0.2 & 100 & 100 & 100 & 100 & 60 & 5 \\
\hline 0.5 & 100 & 100 & 100 & 100 & 100 & 0 \\
\hline 5 & 100 & 100 & 100 & 100 & 100 & 0 \\
\hline 10 & 100 & 100 & 100 & 100 & 100 & 0 \\
\hline 20 & 100 & 100 & 100 & 100 & 100 & 0 \\
\hline 30 & 100 & 100 & 100 & 100 & 100 & 0 \\
\hline 40 & 100 & 100 & 100 & 100 & 100 & 0 \\
\hline 50 & 100 & 100 & 100 & 100 & 100 & 0 \\
\hline 60 & 100 & 100 & 100 & 100 & 100 & 15 \\
\hline 70 & 100 & 100 & 100 & 100 & 100 & 10 \\
\hline 80 & 100 & 100 & 100 & 100 & 100 & 0 \\
\hline
\end{tabular}

\section{Discussion}

Organisms living in estuaries and intertidal zones are subjected to stress from rapid changes in salinity and temperature, particularly when they are exposed at low tides. Organisms living in the intertidal zone are generally able to tolerate wide ranges in salinity and temperature (Macler 1988; Matsuyama-Serisawa et al. 
Table 4 Results of logistic regression analysis for survival rates of Chaetomorpha sp.

\begin{tabular}{llllll}
\hline Salinity & Water temperature $\left({ }^{\circ} \mathrm{C}\right)$ & Total number & Survival number & Odds ratio $(95 \% \mathrm{CI})$ & Chi squared test \\
\hline $0.1-80$ & $15-35$ & 1,200 & 1,163 & 1.000 & - \\
$0-80$ & 40 & 260 & 6 & $1,330.637(555.687-3,186.319)$ & $P<0.0001$ \\
0 & $15-35$ & 100 & 29 & $76.955(44.759-132.311)$ & $P<0.0001$ \\
\hline
\end{tabular}

Seaweeds were cultured under different combinations of salinity and water temperatures for 7 days. Combinations were determined from the results of a receiver operating characteristic analysis: CI, confidence interval

Fig. 6 Mean specific growth rates (SGR) of Chaetomorpha sp. under different salinities and water temperatures. Error bars show standard errors for 20 individuals. a SGRs at low salinity $(0-0.5)$; b SGRs over the full salinity range investigated $(0-80)$
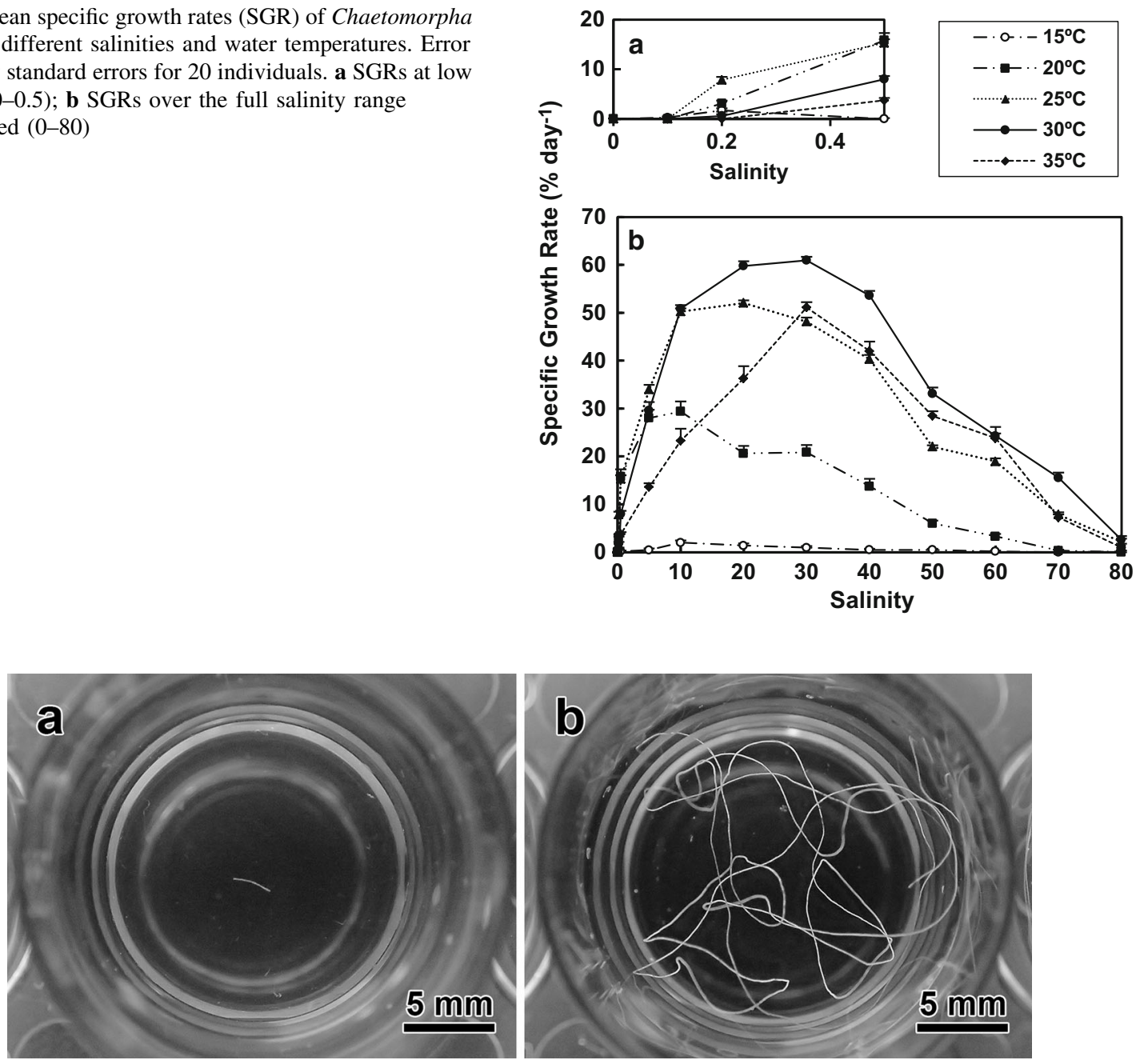

Fig. 7 Chaetomorpha sp. cultured in multiwells. a Filament of $2 \mathrm{~mm}$ at the beginning of the experiment; b filaments grew $>200 \mathrm{~mm}$ by 7 days after starting under a combination of salinity of 30 and water temperature of $30{ }^{\circ} \mathrm{C}$

2004). The salinity ranges in intertidal environments where several green tidal species observed are shown in Table 6. Comparing among green tidal species, it is obvious that the present seaweed, Chaetomorpha sp, has wider tolerance to salinity. Flora in the stagnant waters of the present study was almost monopolized by Chaetomorpha sp., and intertidal species, such as $U$. intestinalis and $U$. clathrata, were only opportunistically observed. Salinity ranged from 3.4 to 90 (Fig. 4) in this study, which is likely one of the reasons that ordinal intertidal species could not establish their communities because of narrower salinity tolerances of Ulva. In contrast, based on our survival experimental result, Chaetomorpha sp. could survive in salinities of 0.1-80. This alga is capable of survive and growth in water environments that widely fluctuate from freshwater to brine, whereas other seaweeds are unable to dominate the population and maintain a dense community throughout the year in stagnant waters. 
Table 5 Results of two-way random-effect analysis of variance for specific growth rates of Chaetomorpha sp.

\begin{tabular}{|c|c|c|c|c|}
\hline Source & $d f$ & Mean square & $F$ value & Significance ( $P$ value $)$ \\
\hline \multicolumn{5}{|l|}{ Salinity } \\
\hline Hypothesis & 4 & $27,012.948$ & 11.993 & 0.000 \\
\hline Error & 48 & $2,252.441$ & & \\
\hline \multicolumn{5}{|l|}{ Water temp. } \\
\hline Hypothesis & 12 & $18,769.030$ & 8.333 & 0.000 \\
\hline Error & 48 & $2,252.441$ & & \\
\hline \multicolumn{5}{|c|}{ Interaction $(\mathrm{S} \times \mathrm{W})$} \\
\hline Hypothesis & 48 & $2,252.441$ & 118.688 & 0.000 \\
\hline Error & 1,235 & 18.978 & & \\
\hline
\end{tabular}

Fig. 8 Change in lengths of Chaetomorpha sp. cultured under optimum salinities in different water temperatures. Error bars show standard errors for 20 individuals

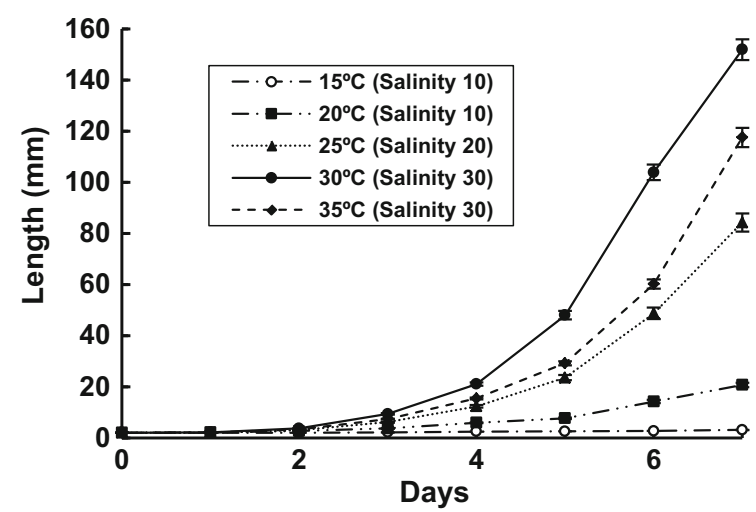

Table 6 Salinities, water temperatures, and growth rates ranges of the major green tidal seaweeds

\begin{tabular}{|c|c|c|c|c|c|}
\hline Taxon & $\begin{array}{l}\text { Salinity } \\
\text { (psu) }\end{array}$ & $\begin{array}{l}\text { Water } \\
\text { temp. }\left({ }^{\circ} \mathrm{C}\right)\end{array}$ & $\begin{array}{l}\text { Growth } \\
\text { rate } \\
\left(\% \text { day }^{-1}\right)\end{array}$ & Condition & References \\
\hline \multicolumn{6}{|l|}{ Ulvales } \\
\hline Ulva sp. & $5-45$ & & $5-23$ & Laboratory culture & de Paula Silva et al. (2008) \\
\hline $\begin{array}{l}\text { U. clathrata (as } \\
\text { Enteromorphaclathrata) }\end{array}$ & $26-33$ & $26-29$ & $6-12$ & Outdoor culture & Copertino et al. (2009) \\
\hline U. fasciata & $34-41$ & $25-33$ & $\sim 0.3$ & $\begin{array}{l}\text { Chamber in pond } \\
\text { draining fishpond }\end{array}$ & Mmochi et al. (2002) \\
\hline U. intestinalis & $0.6-27.7$ & & & Estuary & McAvoy and Klug (2005) \\
\hline$U \cdot$ pertusa & $6.6-66.2$ & 20 & $10-23$ & Laboratory culture & Kakinuma et al. (2004) \\
\hline U. prolifera (as E. prolifera) & $0.3-33.1$ & $7.5-21.6$ & & Natural & Ohno and Takahashi (1988) \\
\hline$U$. reticulata & $23-40$ & $27.3-29.6$ & $1.2(2.7)$ & Cage in channel & Msuya and Neori (2002) \\
\hline \multicolumn{6}{|l|}{ Cladophorales } \\
\hline $\begin{array}{l}\text { Present species } \\
\quad(\text { Chaetomorpha sp.) }\end{array}$ & $0.2-80$ & $15-35$ & $2-60$ & Laboratory culture & Present study \\
\hline C. indica & $5-45$ & & $5-30$ & Laboratory culture & de Paula Silva et al. (2008) \\
\hline C. linum & $20-45$ & $25-32$ & $<7.5$ & Laboratory culture & $\mathrm{Xu}$ and Lin (2008) \\
\hline C. valida & $17-29$ & & $5-25$ & Laboratory culture & Deng et al. (2012) \\
\hline Cladophora coelothrix & $15-45$ & & $12-20$ & Laboratory culture & de Paula Silva et al. (2008) \\
\hline Rhizoclonium sp. & $10-40$ & $\begin{array}{l}\text { 18-22 } \\
\quad \text { (in natural } \\
\text { site) }\end{array}$ & $4-19$ & Laboratory culture & $\begin{array}{l}\text { Matsuyama-Serisawa et al. } \\
\text { (2004) }\end{array}$ \\
\hline R. riparium & $0.1-34$ & 20 & $2-10$ & Laboratory culture & Imai et al. (1997) \\
\hline
\end{tabular}


It is well-known that water temperature affects seaweed growth (Xu and Lin 2008). The upper lethal temperature limits of common green tidal seaweeds growing in intertidal zones, estuaries, and lagoons considered to be $33{ }^{\circ} \mathrm{C}$ and under (Table 6). In contrast, Chaetomorpha sp. survived well (40-100\%) and grew $\left(50 \%\right.$ day $\left.^{-1}\right)$ at $35{ }^{\circ} \mathrm{C}$, but almost all thalli died at $>40{ }^{\circ} \mathrm{C}$ in the laboratory experiments. Our results, including the ROC analysis, showed that the upper lethal limit of Chaetomorpha sp. was $35-40{ }^{\circ} \mathrm{C}$. Overall, the tolerance to high water temperature of this species enables it to grow in the relatively higher water temperatures commonly found in stagnant tropical waters.

Plants comprising the green tide can inordinately grow under favorable environmental conditions (Keesing et al. 2011). The maximum SGRs of plants belonging to genera related to the green tide are $23 \%$ day $^{-1}$ for Ulva sp., $23 \%$ day $^{-1}$ for $U$. pertusa, $<20 \%$ day $^{-1}$ for $U$. clathrata, $12 \%$ day $^{-1}$ for $C$. indica, $19 \%$ day $^{-1}$ for Rhizoclonium sp., and $20 \%$ day $^{-1}$ for Cladophora coelothirix (Table 6). In contrast, the maximum SGR of the present species was approximately, $60 \%$ day $^{-1}$ under optimum conditions (salinity $20-30$ and $30{ }^{\circ} \mathrm{C}$ ), which was consistent with distribution frequencies of this alga in the field survey (Fig. 4). The maximum growth rate of Chaetomorpha sp. was more than two times higher than that of the aforementioned species, which enables this alga to rapidly occupy vacant niches in stagnant water.

Desiccation negatively affects seaweed growth and photosynthesis (Yamochi 2013). Even during the culture duration (7 days), terminal filament lengths were shorter in the growth pattern experiment, in which we performed daily length measurements compared with those in the SGR experiment, which was static cultured. We consider that the low growth in the growth pattern experiment was affected by desiccation.

\section{Conclusion}

Our fieldwork results indicate that Chaetomorpha sp. was distributed in stagnant environments widely ranging in salinity and water temperature. Laboratory experiments indicate that this species has characteristics of high euryhalinity, eurythermy, and a high growth rate. The euryhaline and eurythermal nature of this seaweed enables it to settle in fluctuating stagnant water environments from 0.1 (fresh water) to 80 (brine) at temperatures $<35^{\circ} \mathrm{C}$, and the high growth nature enables it to rapidly occupy vacant niches in stagnant water.

Acknowledgments This study was performed as part of the international research project "Development of Aquaculture Technologies for Suitable and Equitable Production of Aquatic Products in Tropical Coastal Areas" conducted by the Faculty of Agricultural Technology, KMITL and Fisheries Division, JIRCAS. The field surveys were partially financed by a research grant from the Toyota Foundation (D09-R-0648). The authors would also like to sincerely thank Professor Emeritus Dr. Masao Ohno, Kochi University, Japan for giving useful comments on this manuscript. We thank the National Research Council of Thailand (NRCT), particularly, Ms. Pannee Panyawattanaporn, Chief, Section of Foreign Researcher Management, and Ms. Rapeeporn Reakspuit for providing useful advice to conduct this study in Thailand. The authors also greatly appreciate Dean Sakchai Choochote, and the Head of Fisheries group, Dr. Paveena Taveekijakarn, Faculty of Agricultural Technology, KMITL for their helpful advice. We thank Dr. Masayoshi Saito, Program Director, JIRCAS, and Dr. Hiroyuki Sudo, Project Leader, JIRCAS, for their constructive comments.

Conflict of interest The authors declare that they have no competing interests.

Authors' contributions The work presented here was carried out in collaboration between the authors. IT conceived of the study, designed methods, performed surveys and experiment and drafted the manuscript. TM participated in the sequence experiment, DA coordinated and performed field surveys, JS, CM, SK, HS, PP, IY carried out field surveys and growth experiments, MG participated in experimental coordination. YM participated in experimental coordination and helped draft manuscript. KH conceived of the study, designed methods, and drafted the manuscript. All authors read and approved the final manuscript.

Open Access This article is distributed under the terms of the Creative Commons Attribution License which permits any use, distribution, and reproduction in any medium, provided the original author(s) and the source are credited.

\section{References}

Bolton JJ, Robertson-Andersson DV, Shuuluka D, Kandjengo L (2009) Growing Ulva (Chlorophyta) in intergrated systems as a commercial crop for abalone feed in South Africa: a SWOT analysis. J Appl Phycol 21:575-583. doi:10.1007/s10811-0089385-6 
Caffrey JM, Monahan C (1999) Filamentous algal control using barley straw. Hydrobiologia 415:315-318. doi:10.1023/A: 1003884211027

Copertino MS, Tormena T, Seeliger U (2009) Biofiltering efficiency, uptake and assimilation rates of Ulva clathrata (Roth) J. Agardh (Chlorophyceae) cultivated in shrimp aquaculture waste water. J Appl Phycol 21:31-45. doi:10.1007/s10811-0089357-x

Coppejans E, Prathep A, Leliaert F, Lewmanomont K, De Clerck O (2010) Seaweeds of Mu Ko Tha Lae Tai (SE Thailand): methodologies and field guide to the dominant species. Biodiversity Research and Training Program (BRT), Bangkok

Cruz-Suárez LE, León A, Peña-Rodríguez A, Rodríguez-Peña G, Moll B, Ricque-Marie D (2010) Shrimp/Ulva co-culture: a sustainable alternative to diminish the need for artificial feed and improve shrimp quality. Aquaculture 301:64-68. doi:10. 1016/j.aquaculture.2010.01.021

de Paula Silva PH, McBride S, de Nys R, Paul NA (2008) Integrating filamentous 'green tide' algae into tropical pond-based aquaculture. Aquaculture 284:74-80. doi:10.1061/j.aquaculture.200807.035

Deng Y, Tang X, Huang B, Ding L (2012) Effect of temperature and irradiance on the growth and reproduction of the green macroalga, Chaetomorpha valida (Cladophoraceae, Chlorophyta). J Appl Phycol 24:927-933. doi:10.1007/s10811-0119713-0

Guiry MD, Guiry GM (2014) AlgaeBase. World-wide electronic publication, National University of Ireland, Galway. http://www. algaebase.org. Accessed 8 Oct 2014

Hamano K, Tsutsui I, Songphatkaew J, Aue-umneoy D, Srisapoome P (2012) A newly developing co-culture system using discarded seaweed to enhance the production of indigenous shrimp species in Southeast Asia. In: Tanaka K, Morioka S, Watanabe S (eds) Sustainable stock management and development of aquaculture technology suitable for Southeast Asia, JIRCAS working report no. 75. Japan International Research Center for Agricultural Sciences, Tsukuba, pp 149-158

Hiraoka M, Ohno M, Kawaguchi S, Yoshida G (2004) Crossing test among floating Ulva thalli forming 'green tide' in Japan. Hydrobiologia 512:239-245. doi:10.1023/B:HYDR.0000020332.12641.a2

Imai M, Katayama N, Yamaguchi Y (1997) Effects of salinity on growth, photosynthesis and respiration in a freshwater alga Rhizoclonium riparium (Chlorophyceae, Cladophorales). Phycol Res 45:233-237. doi:10.1111/j.1440-1835.1997.tb00082.x

Kakinuma M, Kuno Y, Amano H (2004) Salinity stress responses of a sterile mutant of Ulva pertusa (Ulvales, Chlorophyta). Fish Sci 70:1177-1179. doi:10.1111/j.1444-2906.2004.00921.x

Keesing JK, Liu D, Fears P, Garcia R (2011) Inter- and intra-annual patterns of Ulva prolifera green tides in the Yellow Sea during 2007-2009, their origin and relationship to the expansion of coastal seaweed aquaculture in China. Mar Pollut Bull 62:1169-1182. doi:10.1016/j.marpolbul.2011.03.040

Lehvo A, Bäck S (2001) Survey of macroalgal mats in the Gulf of Finland, Baltic Sea. Aquat Conserv 11:11-18

Leliaert F, Boedeker C (2007) Cladophorales. In: Brodie J, Maggs CA, John DM (eds) The green seaweeds of Britain and Ireland. The British Phycological Society, London, pp 131-183

Lewin J (1966) Silicon metabolism in diatoms. V. Germanium dioxide, a specific inhibitor of diatom growth. Phycologia 6:1-12. doi:10.2216/i0031-8884-6-1-1.1

Lewmanomont K, Ogawa H (1995) Common seaweed and seagrasses of Thailand. Kasetsart University, Bangkok

Lewmanomont K, Wongrat L, Supanwanid C (1995) Algae in Thailand. Office of Environmental Policy and Planning, Thailand

Liu D, Keesing JK, Xing Q, Shi P (2009) World's largest macroalgal bloom caused by expansion of seaweed aquaculture in China. Mar Pollut Bull 8:888-895. doi:10.1016/j.marpolbul.2009.01.013

Liu D, Keesing JK, He P, Wang Z, Shi Y, Wang Y (2013) The world's largest macroalgal bloom in the Yellow Sea, China: formation and implications. Estuar Coast Shelf Sci 129:2-10. doi:10.1016/j.ecdd.2013.05.021

Maceiras R, Rodríguez M, Cancela A, Urréjola S, Sánchez A (2011) Macroalgae: raw material for biodiesel production. Appl Energy 88:3318-3323. doi:10.1016/j.apenergy.2010.11.027

Macler BA (1988) Salinity effects on photosynthesis, carbon allocation, and nitrogen assimilation in the red alga, Gelidium coulteri. Plant Physiol 88:690-694. doi:10.1104/pp.88.3.690

Matsuyama-Serisawa K, Serisawa Y, Tanaka J (2004) Growth, maturation and photosynthesis of the brackish water alga Rhizoclonium sp. (Cladophoraceae, Chlorophyta) in relation to salinity. Phycol Res 52:204-210. doi:10.1111/j.1440-183. 2004.00341.x

McAvoy KM, Klug JL (2005) Positive and negative effects of riverine input on the estuarine green alga Ulva intestinalis (syn. Enteromorpha intestinalis) (Linnaeus). Hydrobiologia 545:1-9. doi:10.1007/s10750-005-1923-5

Mmochi AJ, Dubi AM, Mamboya FA, Mwandya AW (2002) Effects of fish culture on water quality of an integrated mariculture pond system. West Indian Ocean J Mar Sci 1:53-63

Morand P, Merceron M (2005) Macroalgal population and sustainability. J Coast Res 21:1009-1020. doi:10.2112/04-700A.1

Msuya FE, Neori A (2002) Ulva reticulata and Gracilaria crassa: macroalgae that can biofilter effluent from tidal fishponds in Tanzania. West Indian Ocean J Mar Sci 1:117-126

Ohno M (1993) Cultivation of the green algae, Monostroma and Enteromorpha "Aonori". In: Ohno M, Critchley AT (eds) Seaweed cultivation and marine ranching. Japan International Cooperation Agency (JICA), Kanagawa

Ohno M, Takahashi I (1988) The horizontal and vertical distribution of the food alga Entromorpha prolifera in Shimanto River, southern Japan, vol 10. Report of Usa Marine Biological Institute, Kochi University, pp 45-54

Provasoli L (1966) Media and prospects for the cultivation of marine algae. In: Watanabe A, Hattori A (eds) Culture and collections of algae. Japanese Society of Plant Physiologists, Tokyo

Tanaka J (2001) Taxonomy and morphology of macroalgae in brackish waters (23) Cladophoracean algae 4. Salinity tolerance of Rhizoclonium spp. Aquabiology 23, Seibutsu Kenkyusha, Tokyo, pp 594-598

Tsutsui I, Huỳnh QN, Nguyễn HD, Arai S, Yoshida T (2005) The common marine plants of Southern Vietnam. Japan Seaweed Association, Kochi 
Tsutsui I, Kanjanaworakul P, Srisapoome P, Aue-umneoy D, Hamano K (2010) Growth of giant tiger prawn, Penaeus monodon Fabricius, under co-culture with a discarded filamentous seaweed, Chaetomorpha ligustica (Kützing) Kützing, at an aquarium-scale. Aquac Int 18:545-553. doi:10.1007/s10499-009-9274-2

Tsutsui I, Hamano K, Aue-umneoy D, Songphatkaew J, Srisapoome P, Ruangsomboon S, Klomkling S, Ganmanee M, Taveekijakarn P, Maeno Y (2012) Common underwater plants in coastal areas of Thailand. JIRCAS International Agriculture Series 21. Japan International Research Center for Agricultural Sciences, Tsukuba

Xu Y, Lin J (2008) Effect of temperature, salinity, and light intensity on the growth of the green macroalga, Chaetomorpha linum. J World Aquac Soc 39:847-851. doi:10.1111/j.1749-7345.2008.00223.x

Yamochi S (2013) Effect of desiccation and salinity on the outbreak of a green tide of Ulva pertusa in a created salt marsh along the coast of Osaka Bay, Japan. Estuar Coast Shelf Sci 116:21-28. doi:10.1016/j.ecss.2012.07.002 